\title{
Antropolojik Yönüyle Yaşayan Rumkale ve Çevresi
}

\author{
DOI: $10.26466 /$ opus.879631
}

\author{
Güray Alpar * \\ * Doç.Dr, Stratejik Düşünce Enstütüsü, Ankara/Türkiye \\ E-Posta: galpar1965@gmail.com ORCID: $\quad$ 0000-0003-0122-7795
}

\section{Öz}

Bir yerleşim yeri tarihi ve antropolojik özellikleri ile yaşar. Onu yaşatan ayn zamanda ondan kalan hatıralar, anıtlar, eserler ve yazılı belgelerdir. Bunlar kaybolduğunda ise olaylar ve kişiler efsaneleşir ve var ile yok arasında kaybolur gider. Bunun dışında yerleşim yerinin kültürel ve sosyolojik özellikleri de o döneme ilişkin belgeler incelenmek suretiyle bir derece ortaya çıkarlabilir. Günümüzde Antep ili sınırları içerisinde yer alan Rumkale yerleşkesi, bu tanıma en iyi uyan yerlerden birisidir. Derin bir tarih içerisinde birçok medeniyeti yaşamış olan ve birçok kez el değiştirmiş olan bu mekân, her ne kadar son dönemde kendisi ile ilgili bazı bilgiler basında ve medya da yer alsa da daha fazla araştırılmayı hak ediyor. Ancak bu konuda birbirini tekrar eden kalıplaşmış cümleler, Rumkale'yi ve ona ait kültürel değerleri tam olarak izah etmeye yetmiyor. Ona ait değerler giderek azalıyor ve elde kalanlar ise korunmayı hak ediyor. Tarihçi ve antropologlar genelde sıradan insanların günlük yaşamlarına ait bilgiler veren belgelerle daha çok ilgilenirler. Bunun asıl nedeni birçok resmî belgenin ve tarihsel yazınların kişisel ve taraflı bilgileri yansitabileceği düşüncesidir. Yine de belgelerin incelenip yorumlanması ile birçok konu açıklığa kavuşturulabilir. Bu çalışmada Rumkale'ye ait bulunabilen bazı belgelerden hareket ederek ve bölgede yapilan birebir incelemelere dayanilarak bu bölgenin tarihi ve kültürel özellikleri bir derece ortaya konulmaya çalışılmıştır. Kısıtlı bilgilere dayanarak yapılan bu çalışmanın araştırmacılar tarafından daha da geliştirilmesi durumunda Rumkale ve çevresine ait binlerce yıllık birikimin gelecek kuşaklara aktarılması mümkün olabilecektir.

Anahtar Kelimeler: Rumkale, Antep, Kültür, Antropoloji, Tarih. 


\title{
Rumkale and Its Environment from an Anthropological Perspective
}

\begin{abstract}
A settlement lives with its historical and anthropological features. It is also the memories, monuments, artifacts and written documents left from him that keep him alive. When these disappear, they become legendary and disappear between existence and disappearance. Apart from this, the cultural and sociological characteristics of the settlement can be revealed to a certain extent by examining the documents related to that period. Rumkale Campus, which is located within the borders of Antep province today, is one of the places that best suits this definition. This place, which has lived through many civilizations in a deep history and has changed hands many times, deserves to be investigated more, although some information about it has recently appeared in the press and the media. However, repeating stereotypes on this issue are not enough to fully explain Rumkale and its cultural values. His values are decreasing and what remains deserving to be protected. Historians and anthropologists are generally more interested in documents that give information about the daily lives of ordinary people. The main reason for this is the idea that many official documents and historical literature can reflect personal and biased information. However, many issues can be clarified by examining and interpreting the documents. In this study, it was tried to reveal the historical and cultural characteristics of this region to some extent based on the one-to-one examinations made in the region and based on some documents that can be found in Rumkale. In case this study, which is based on limited information, is developed further by the researchers, it will be possible to transfer the thousand years of knowledge of Rumkale and its surroundings to the next generations.
\end{abstract}

Keywords: Rumkale, Antep, Culture, Anthropology, History. 


\section{Giriş}

Kültürel çalışmalar bilgi ve çözümleme biçimlerini açarak, o güne kadar sadece kendi kimliğini yeniden anlama çabasındaki kuramları birtakım sinırlamalar ötesinde yeniden ve güçlü bir şekilde düşünmeye sevk eder (Hall ve Clare,2013, s.31). Tarihçiler ve antropologlar genelde siradan insanların günlük yaşamlarını anlatan ve onların sosyal yaşamlarına ait bilgiler veren belgelerle daha çok ilgilenirler. Bunun başlıca nedeni birçok resmî belgenin ve tarihsel yazınların o yazıyı yazan kişinin kişisel ve taraflı fikirlerini yansıtabileceği düşüncesidir. Sıradan insanlara ait belgeler ise bunun dışında o toplumun işleyişi ile ilgili bilgiler sunabilir. Kavramsallaştırılmış haliyle antropolojinin bir görevi de bireyler arasındaki anlayışı geliştirmeye katkıda bulunmaktır (Wulf,2009, s.11). Derin tarihi geçmişi ile kültürler ve dinler arasında bir geçiş görevini de gören araştırma bölgesinin bu türden barışçıl bir işlevi görmesi de ancak bu şekilde mümkündür. Sosyolojik olarak da sosyologların amacının içinde yaşadığı toplumu anlamaya ve açıklamaya çalışmak olduğu düşünüldüğünde (Erdem, 2019, s.24), Rumkale bölgesinin de bu türden bir çalışmayı hak ettiği açıktır. Konuya bu şekilde yaklaşılmadığı sürece bazılarının sık sık ortaya koyduğu gibi olay, keskin bir biçimde binlerce yıllık Doğu-Batı kavgası (Camous,2019, s.21) şeklinde basit bir anlama indirgenerek anlatılmaya devam edecektir.

\section{Araştırmanın Amacı, Kapsamı ve Yöntemi}

Yapılan araştırmalar esnasında tesadüfen bulunan ve günümüzde Gaziantep'in Nizip İlçesi sınırları içerisinde yer alan Rumkale bölgesine ait, Osmanlı Devleti'nin son dönemlerine ilişkin Osmanlıca aile belgeleri, dönemine ilişkin bilgileri ihtiva etmektedir. Nadir bulunan bu belgelerin kaybolmadan, zamanında Türkçeye çevrilerek yapılan bu araştırmada kullanılması ise orijinal olması yanında bu bölge ve geçmişine dair bazı bilgileri belgeleri ile ortaya koymaktadır.

Belgeler kayıtlarda adı geçen Rumkale eşrafının soyundan gelen Selahattin Yener'den alınmış olup kendisinden belgelerin yayını için gerekli izinler alınmıştır. Bu bölge halkından olan ve bölgeyi iyi tanıyan şahsın, bölgenin kültürel özelliklerine ilişkin vermiş olduğu 
derinlemesine bilgiler şüphesiz ki çok kıymetlidir. Bölgede bizzat yapılan araştırmalar ile bu bölgenin bir derece tanınıyor olması da hakkında çok fazla bilgi bulunmayan Rumkale'nin anlaşılır olmasına katkı sağlamıştır. $\mathrm{Bu}$ anlamda bölgede bizzat bulunulan 1 yıl süresince sık sık bölgede araştırmalar yapılması da konunun daha iyi anlaşılıp, anlatımına katkı sağlamıştır. Yapılan bu çalışmalar nazari olarak yapılan araştırma ve literatür taraması ile de desteklenmiştir.

\section{Bulgular}

Rumkale ve civarında yapılan kazılarda ele geçen çakmak taşları ve bundan yapılmış el aletleri ile kalıntılar, bölgenin Paleolitik dönemden insanlar tarafından kullanıldığını ispatlamaktadır. Bilindiği gibi bu dönem Kaba Taş Devri ve Yontma Taş Devirlerini kapsayan dönem olup günümüzden yaklaşık 2 milyon yıl öncesinden başlamış ve son buzul çağının bittiği ve tarımın başladığı 12 bin yıl öncesine kadar devam etmiştir.

Rum Kale bölgesindeki kalenin ilk olarak, Asurlular zamanında inşa edildiği sanılmaktadır. Yapılan araştırmalar bölgenin, MÖ 800'de Asur Kralı II. Salmanazar döneminde ele geçirdiğine işaret etmektedir. Stratejik öneminden dolayı daha sonraları bu bölge ve civarı; önce Hititler tarafından, daha sonra da Med ve Persler tarafından ele geçirilmiştir. Bundan sonra ise bölge Romalılar tarafından işgal edilmiştir.

Geç Roma Dönemi bir anlamda, Roma İmparatorluğunun MS III. yüzyıldan itibaren zayıflamaya başlaması ile MS VI. yüzyıl arasındaki zaman dilimi olarak isimlendirilmektedir (Mitchell,2016). Bu dönem aynı zamanda Roma imparatorluğu için Paganizmden Hıristiyanlığa geçiş dönemidir (Plevneli, 2017, s.99).

Antik dönemden günümüze kadar Hromklay, Ranculat, Sitamrat, Kala Rhomayra, Kale-i Zerrin, Kal-at el Müslimin ve Kal-at Rum gibi isimlerle anılan Rumkale, Geç Roma ve Ortaçağ mimari özelliklerini taşımaktadır (Taşdemir, 2017).

Daha sonraki dönemlerde bölgede Memluklar, Selçuklular ve Osmanlılar da egemen olmuş ancak hiçbir zaman açık bir Yunan hakimiyeti söz konusu olmamıştır. Osmanlılar, Bizans'tan ele geçirdikleri Avrupa topraklarına, "Roma Ülkesi" manasına gelen "Rumeli" ismini 
verdiler. Çağdaşları Müslüman hükümdarlar ise Osmanlı Sultanı'na Kayser-i Rum (Romanın Sezar'1) diyorlardı (Alpar, 2014, s.171). Rumkale ismini de bu anlamda değerlendirmek gerekir.

\section{Bölgenin İsminin Rumkale Olması}

Aslında, Anadolu'daki bütün Bizanslılar "Rum" olarak isimlendirilip, Yunanlılarla ilişkilendirilmiş olsa da bu tam olarak doğru değildir. Yunanlıların hiçbir dönemde, Anadolu'nun tamamını ele geçirmesi gibi bir durum söz konusu olmamıştır. Romalılar, Latince konuşurdu. Roma İmparatorluğu, Batı ve Doğu Roma İmparatorluğu olarak ikiye ayrıldıktan sonra Katolik olan Batı Roma'ya karşı Ortodoks Doğu Roma'da bir tepki başladı. Batı Roma'nın dili Latinceydi. Belli bir döneme kadar Doğu Romanın, hatta Bizanslıların dili de Latinceydi. Ancak Katolik kilisesine duyulan öfke Yunancaya geçişi hızlandırdı ve MS 600'lü yıllarda Yunanca, Batı Roma'nın resmi dili olarak ilan edildi (Roberts, 1996, s.113). Aslında Yunancayı kabul ettiren 610-641 yılları arasında hükümdar olan Ermeni asıllı Bizans İmparatoru, Heraclius idi. Bizanslılar bile sona erdirildikleri 1453 yılına kadar kendilerini "Romalı" olarak tanımlarken, her nedense Yunanlı olmadığ 1 halde sadece resmi dili Yunanca olmasindan dolayı ve sirf "Yunanca okuyup yazıyor" diye Hristiyan bütün unsurlar, hatta, "Hristiyan Türkler bile" Rum olarak isimlendirilmiştir. Bu tamamen bilgi eksikliğinden kaynaklanmaktadır. Bu yanılgı dolayısıyladır ki, Türkiye ve Yunanistan arasındaki 1923 Lozan Barış Antlaşmasına ek sözleşme ile yapılan nüfus mübadelesi din esasına göre yapıldığından, Ortodoks Hristiyanlarla birlikte, Türkçeden başka dil bilmeyen, Ortodoks Türk Gagavuzlar ve Karamanlı Ortodoks Türkler de Yunanistan'a gönderilmiştir (İbrahim, 2006, s.285).

Rumkale, halen Gaziantep'in Nizip ilçesi sınırlarında Kamışlı köyünün arazisi içinde bulunmaktadır. Rumkale'nin ulaşım bakımından Gaziantep'in Nizip İlçesi'nden ziyade Yavuzeli ilçesine $(25 \mathrm{~km}$.) yakınlı̆̆ ve Fırat Nehir barajı karşısında bulunan Halfeti ilçesinin dibinde bulunması, bu tarihi mekanının nereye ait olduğu konusunda bu yerleşim yerleri arasında günümüzde tartışmalar yaşanmasına neden olmaktadır. Kale Gaziantep ilinin 62 km kuzeydoğusundadır. 
Bu noktada Baraj Gölü altında kalan Halfeti ilçesinin yerinin değiştirilmesi ile Osmanlı İmparatorluğu döneminde Halep'e bağlı olması ise ayrica incelenmesi gereken bir konudur.

Osmanlı Döneminde basılan haritalar incelendiğinde de o dönemde Rumkale bölgesinin Halep merkezi ile aynı bölge içinde gösterildiği görülür.

\section{Rumkale'nin Konumu}

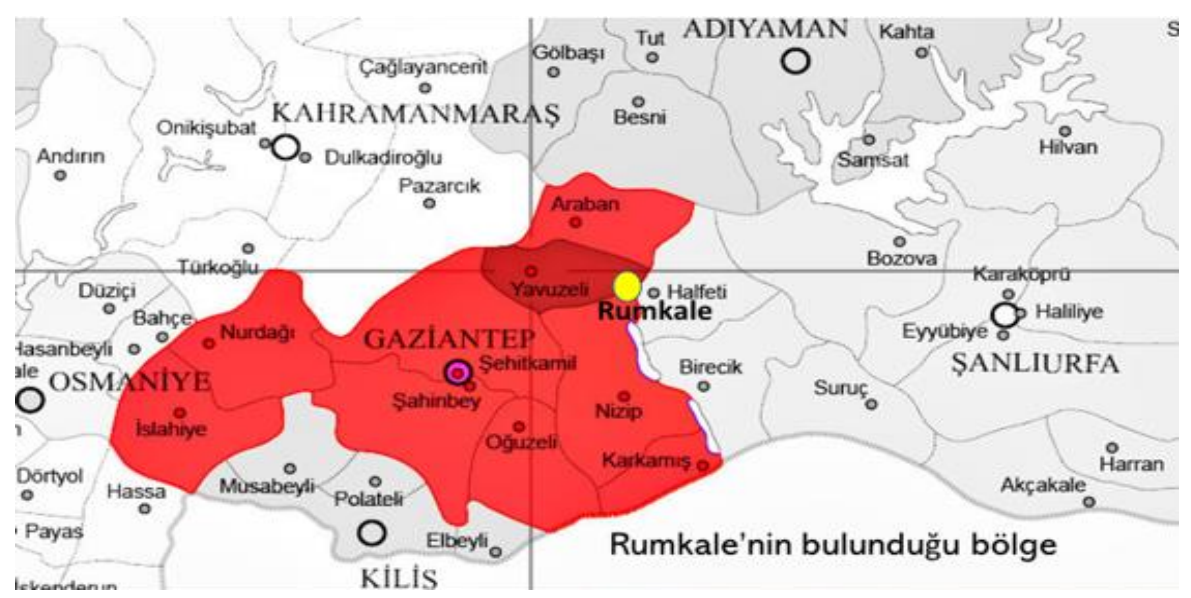

Resim 1. Rumkale'nin bulunduğu bölgenin haritada görünümü

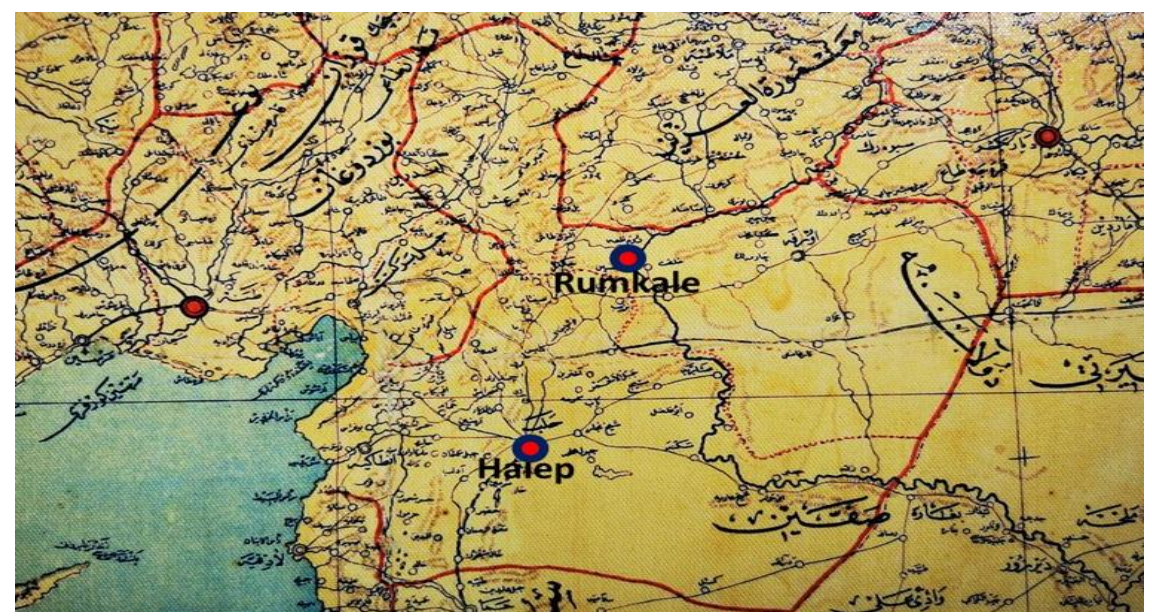

Resim 2. Rumkale ve Halep'in aynı idari birim içinde yer aldı̆̆ı harita 
Kale günümüzde Nizip-Birecik Baraj gölünün yanında, Fırat Nehri ile Yavuzeli'nden gelen Merzimen Çayı'nın birleşim noktasında yüksek kayalarla kaplı bir tepe üzerinde muhteşem bir konumda bulunmaktadır.

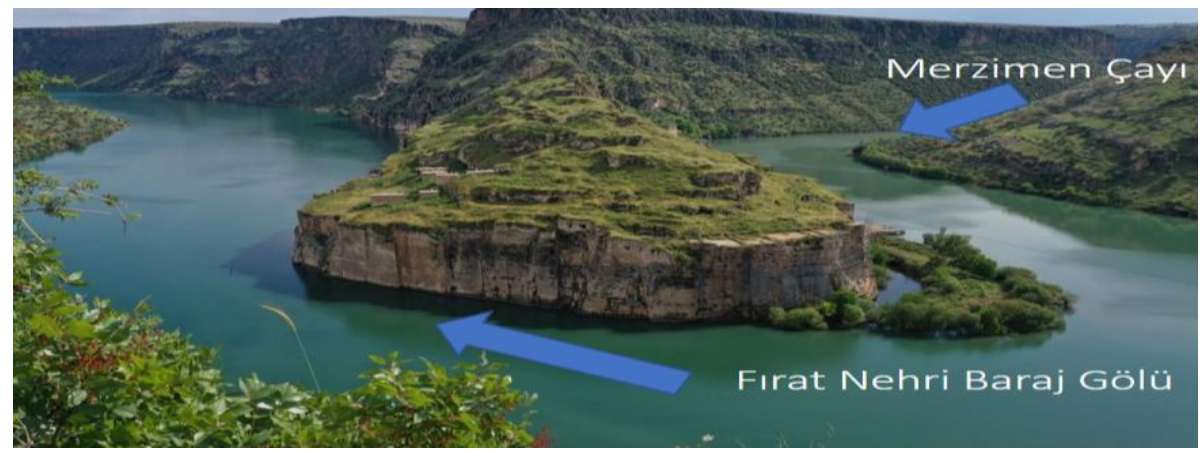

Resim 3. Rumkale'nin bugünkü görünümü (Fotoğraf: Ahmet Barı)

\section{Kale ve Üzerindeki Yapıların Özellikleri}

Kalenin Doğu'dan Fırat Nehri üzerinde ve batı tarafından Merzimen Çayı üzerinde iki ana girişi var. Fırat nehri tarafında 75 metre derinlikte bir kuyu bulunmaktadır.

Nehirden ulaşıma imkân vermesi ve stratejik konumu ile ticaret yollarına yakın olmasından dolayı bölge birçok dönemde önemli bir ticaret merkezi olmuştur. Bölge, Nemrut Dağı ile ünlü olan Kommagene Krallığının başkenti Samsat'a, yakın olması nedeniyle kervanların yolu üzerinde bulunuyordu. Firat ve Dicle nehirleri arasında yer alan Kommagene Krallığı'nın doğu sınırları Firat nehrine, yani Rumkale civarına dayanıyordu. Commagene Krallığı, Muhteşem ordusu ile uzun süre Romalılara dayandı ancak MS 71 yılında Roma ordusuna yenildiler ve ünlü ağır zırhlı süvarileri ve muhteşem okçuları lağvedilerek Roma ordusuna katıldılar.

Halen üzerinde Aziz Nerses Kilisesi (Yapımı MS 1175 yılları), Barşavma Manastırı (13. yüzyıl) ile çok sayıda su sarnıcı, kuyu, hendek ve tarihi binalar yer almaktadır. Kale dikkatle incelendiğinde insanı hayran bırakan bir yapıdadır. Bu incelemede, doğa ve mimarinin birbirine geçmiş ve tam bir uyum içerisinde olduğu görülür. Yine, nerede kayalık biter, 
nerede insan yapımı eserler başlar adeta birbirine karışmış gibidir. $\mathrm{Bu}$ durumu 1836-1839 yılları arasında Osmanlıda askeri uzman ve danışman olarak görev yapan ve Mısır Ordusu ile Nizip'te yapılan savaşa da iştirak eden, Prusyalı Mareşal Moltke'de (Moltke,2017) 1838 yılında kaleye yapmış olduğu ziyaret esnasında açıkça ifade etmiştir.

3500 m2'lik bir alana sahip Kale'nin, bazı yönlerinin zaten doğal uçurum olduğu da rahatça görülür. Rumkale halen üç yönden sularla çevrili durumdadır. Bunlar bazı bölümlerde sert kalker kesme taşlarla yapılan surlarla desteklenmiştir. Kalenin güney yönündeki kayalıklar ise 12. Yüzyılda, 30 metre derinliğinde oyularak uçurum ve hendek durumuna getirilmiştir. Bu suretle savunması güçlendirilerek, kalenin kara ile irtibatı kesilmiştir. Kale savunmaya uygun durumdadır. Ayrıca kaleden Fırat nehrine doğru gizli bir geçidin olduğu rivayet edilmektedir. Kalenin eteklerinde ise su kenarında "aşağı şehir" diye bir yerleşim yeri daha bulunmaktayd.

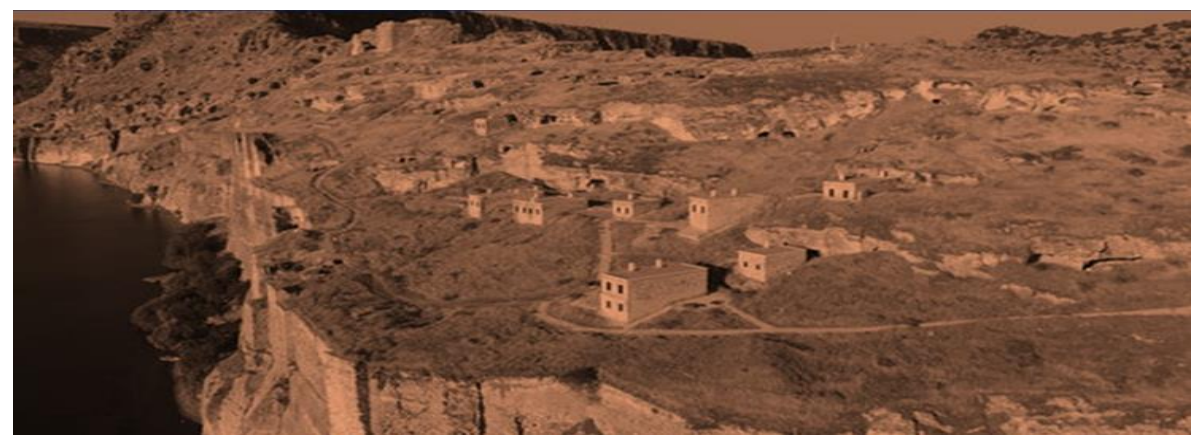

Resim 4. Rumkale'de tarihi yapıların görünümü

\section{Bölgenin Hıristiyanlık Açısından Önemi}

Bölgenin Hristiyanlık açısından dini önemi anlatılara dayanmaktadır. Döneminde dini bir merkez olma özelliğini de taşıyan Rumkale'de, tarihi anlatılara göre, Romalılar döneminde Hz. İsa'nın havarilerinden birisi olan Hohannes (Yuhanna)'in ikamet ettiği ve kayalık bir mağara içinde İncil'in bir kopyasını çoğalttığı söylenmektedir. Yine rivayete göre bu kopya, saklandığı bu mağaradan Beyrut'a götürülmüştür. Yuhanna, Hz. İsa'nın 12 havarisi arasında öldürülmeyen ve kendi eceliyle ölen tek 
havari olarak bilinmektedir. Tahmini ölüm tarihi MS 100'dür (National Geographic, Christianity.com). Hıristiyan dünyasında yazılmış yüzlerce İncil bulunmakta iken, toplanan konsiller tarafından, bunlardan Yuhanna, Markos, Luka ve Matta İncilleri, sahih İncil olarak kabul edilmiş ve bunların dişındaki İnciller "uydurma İncil" olarak kabul edilmişlerdir (Murphy, 2003, s.21-34). Rumkale, ayrıca 1100'lü yıllarda Şair Aziz Nerses'in, Hıristiyan mezheplerini birleştirilmesi maksadıyla yapmış olduğu toplantılar nedeniyle de bilinmektedir. Söylentilere göre Aziz Nerses, bu kalede Yakubi ve Kayşum Başpatrikleriyle toplantılar yapmıştır. 1200'lü yıllarda Rumkale bölgesinde çok Yakubi yaşıyordu ve nedenle Yakubi Patriği 2. Ignace Rumkale'de bir kilise yaptırmıştı ve patrik makamı olarak burayı seçmişti.

Bölge Hıristiyanlık Dini içerisindeki ilk çatışmaları da bünyesinde saklar. Aslında Süryaniler bu bölgede ilk Hıristiyan olan topluluklardı. Batılılar, Süryanileri dışlamak maksadıyla onlardan bazıları için "Yakubi" ifadesini kullanmışlardır. Süryaniler MS 451 tarihinde bir araya gelen Kadıköy Konsili'ne kadar diğer Hıristiyan topluluklarla aynı görüşü paylaşıyorlardı.

Ancak Roma ve Bizans arasındaki dini ayrılıklar ve nedeniyle, Süryaniler Bizanslıların acımasızca başlattığı sindirme politikaları ile karşı karşıya kaldılar (Ürek, 2013, s.108,109). Bunun sonucu Nasturi ve Yakubiler olarak ikiye ayrıldılar. Yakubiler İsa'nın, iki değil tek tabiatlı olduğuna inanyorlardı. Bu nedenle diğer Hıristiyan inançlarının baskılarına maruz kaldılar ve Chalcedon Konsülü tarafından aforaz edildiler. Süryaniler arasında Bizans kilisesine boyun eğenler ise Melki olarak isimlendirildiler. Daha sonra da Süryaniler üzerinde Hiristiyan baskısı devam etti. İslam Dininin bu bölgeye gelmesi ise Yakubi ve Nasturiler için bir kurtuluş gibiydi. Bu dönemden sonra Süryanilerle Müslüman ahali arasında bir yakınlaşma yaşandı. 16 yüzyıldan itibaren ise misyonerlerin etkisiyle, Katolikleştirilen ve daha sonrasında da Protestanlaşan Süryaniler oldu (Tahincioğlu, 2011, s.49).

\section{Halk Arasında Rumkale ile İlgili Anlatılar}

Rumkale ile ilgili anlatılanlar sadece Yuhanna ile sınırlı değil. Bölgede yaşayanların bugün dahi konuştuğu başka söylentiler de var. Bunların bir 
kısmı efsaneye bile dönüşmüş. Buna göre Rumkale'de yaşamış bir kralın, Nergis isimli güzel kızına bir çoban âşık olmuş. Bunu öğrenen Kral çobanı öldürmüş, kızının ise Rumkale'den çıkışını yasaklamış. Sevdiğinin ölümüne dayanamayan kı, bir gün kendisini kalenin kuyusuna atmış. Kızın ölümünden sonra ise bu kuyuda bir çiçek açmış ve çiçeğe "Nergis" ismi verilmiş. Rivayet odur $\mathrm{ki}$, bu çiçek dünyada açan ilk çiçekmiş. Bu hikâyenin doğru olup olmadığı bilinmiyor ancak açık olarak bilinen şey "Karagül" bitkisinin dünyada sadece bu bölgede yetişiyor olması. Kokusu ile görünümünü yetiştiği topraktan alan ve ilkbahar ve sonbahar aylarında açan Karagül bitkisi sadece bu bölgede yetişiyor ve reçel, lokum, krem, kolonya, parfüm ve sabun gibi ürünler yapılıyor.

Nergis çiçeği ile ilgili başka bir rivayette ise; Rumkale beyinin kendinden sonra yerine geçecek Nergis isimli yakışıklı bir oğlu varmış. Öyle ki, onu gören bütün kızlara ona âşık olurlarmış.

Bir gün Rumkale saldırıya uğramış. Kale beyi oğlunu korumak için kalenin kuyusuna saklamış. Kuyunun suyuna bakan çocuk, kendini suda görmüş ve daha iyi görmek için eğilince, kuyunun dibine ve oradan Fırat nehrine yuvarlanarak suda boğulmuş. Boğulduğu yerde bir çiçek bitmiş ve adına "Nergis" denilmiş. Dünyada en güzel kokan çiçeklerden birisi olan Nergis, buradan bütün dünyaya yayılmış fakat hiçbir yerde buradaki kadar güzel kokmamış.

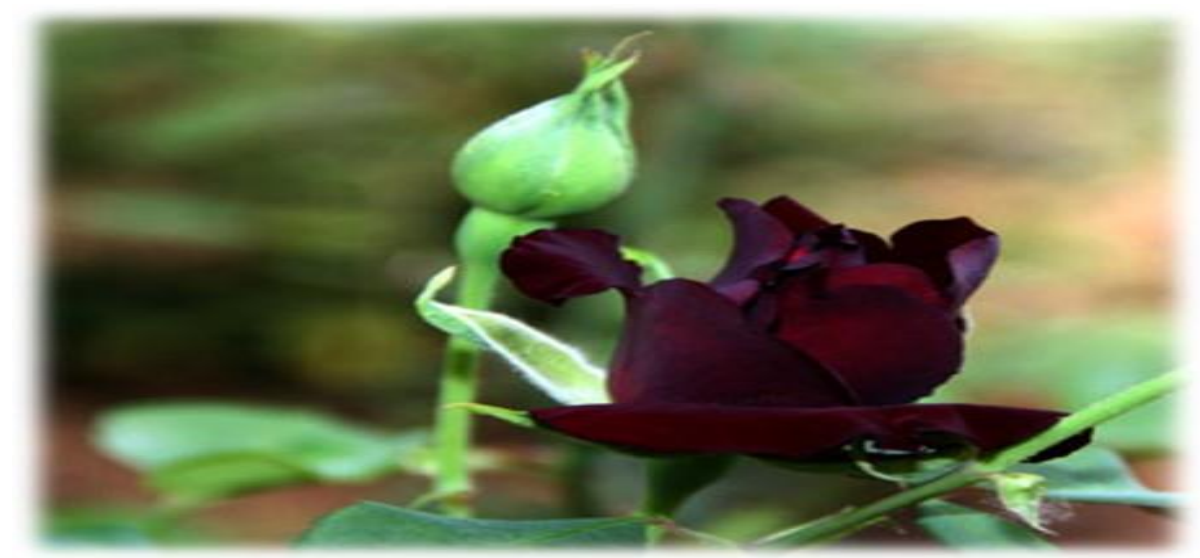

Resim 5. Rumkale civarında yetişen Nergis çiçekleri 


\section{Kalenin Müslümanlar Tarafından Ele Geçirilmesi ve Sonrasındaki Konumu}

Bu kalenin Müslümanlar tarafından ele geçirilmesi savunmaya elverişli yapısı nedeniyle öyle kolay olmamış. Memlük Sultanı Melik el-Eşref tarafından 1279 yılında kuşatılan kale ancak 1292 yılında fethedilmiştir. Fethedildikten sonra yıkık ve dökük bir halde bulunan bu kaleler. Suriye Naibi Sancar Suca tarafından elden geçirilerek iyileştirilmiş ve buralar "Kal'at el Müslimin" olarak isimlendirilmiştir.

Daha sonraları ise bu bölgeler "Altın Kale (Kale-i Zerrin) olarak isimlendirilmiştir. Kale, Memluklar tarafından bir uç kalesi olarak kullanılması düşünülmesine rağmen bir daha eski parlak dönemini yaşayamamıştır. 1516 yılında ise Kale, Osmanlılar tarafından ele geçirilmiş ve Halep vilayetine bağlı Birecik kazasına bağlanmıştır.

Kalenin ele geçirilmesinden sonra Hıristiyan ahaliye dini özgürlükleri tanınmış, dini yapıları asla tahrip edilmemiş, kullanılmadığı dönemlerde dahi bazı yapılar yıkılmayarak camiye çevrilerek kullanılmıştır. Bugün dahi bu eserlerden bazılarının ayakta olması bu hoşgörünün en açık ifadesidir.

Günümüzde kalan ve zarar gören eserlerin restorasyonu için gerekli resmi ihaleler yapılmıştır. Bu kapsamda Gaziantep Valiliği Yatırım İzleme ve Koordinasyon Başkanlığı tarafından, iki yıl içinde tamamlanmak üzere Rumkale Barşavma Manastırı ve Surların restorasyonu için 5.7 milyon bedelli sözleşme imzalandığı açıklanmıştır.

Kale'nin bulunduğu bölge, Gaziantep ilinin Yavuzeli ilçesine komşudur ve Yavuzeli, Suriye ve Mısır'ı ele geçirmek üzere sefere çıkan Yavuz Sultan Selim'in, bu harekât sırasında konakladığı yerdir. Bu bölgenin Halep'e yakınlığından ve bağlılığından söz edilmişti. Zaten Yavuz Sultan Selim'in Memluklara karşı kazandığı Mercidabık Savaşı da Rumkale ile Halep arasında bir bölge olan ve Peygamber Davud'a ait makamın yer aldığına inancı olan“Dabık” bölgesinde yapılmıştır.

Dabık bölgesi, Asurlular zamanında "Dabigu" adı olarak bilinmektedir. Dabık bölgesi Helep ilinin 40 kilometre kadar kuzeyinde yer almakta olup Antakya ilinden Suriye'nin Menbic şehrine giden giden yol üzerinde yer almaktadır. 
Bu bölge bugün dahi stratejik bir öneme haiz olup, geçmişte gerek Emeviler gerekse Abbasiler zamanında Bizans İmparatorluğuna yapılan akınlar için askeri olarak bir üs olarak hizmet vermekteydi (Türkiye Diyanet Vakfı İslam Ansiklopedisi, Mercidabık Muharebesi Maddesi). Bu bölgenin Halep bölgesi ile tarihten gelen bu bağlılığı Osmanlının son dönemine kadar devam etmiştir.

Evliya Çelebi'de, 17. Yüzyılda Rumkale için; “Bir tepe üzerinde sağlam bir kale vardır, camisi, hamamı ve küçük bir çarşısının bulunur ve çevresindeki bağ, bahçe ve meyvelerin boldur." şeklinde bir açılamada bulunmuştur.

Günümüzde de her ne kadar bir kısmı sular altında kalmış olsa da bölgenin birçok sebze ve meyvenin yetişmesine izin veren bir iklim yapısına sahip olduğu görülmekte olup, bölge arazisi zeytinden, fistığa ve tropikal bazı meyvelere kadar birçok meyve ve sebzenin yetişmesine imkân vermektedir.

Osmanlının son döneminde Rumkale terkedilerek önce nehir kenarına taşınmış ancak buradaki alanın yerleşim için yeterli olmaması nedeniyle Rumkale nehrin karşısına taşınmıştır. Buraya taşınan Rumkale'nin ilk Belediye Başkanı ise Emin Beyin oğlu Ali Bey olmuştur.

Bundan sonra ise Rumkale yerine Halfeti ismini almıştır. Halfeti ilçesi Fırat Nehir yatağının baraj gölüne dönüşmesi üzerine buradan 15 kilometre daha kuzeye taşınmış olup ilk yerinde değildir.

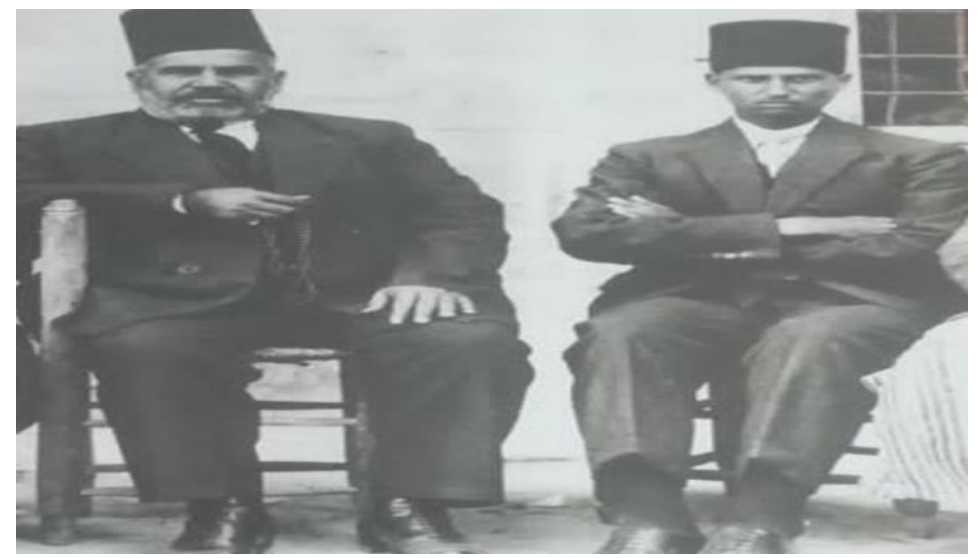

Resim 6. Rumkale (Halfeti) İlk Belediye Başkanı (Solda) 


\section{Bulgu ve Belgelerin Değerlendirilmesi}

Görüşme yapılan Selahattin Yener tarafından aile büyüklerine ait Rumkale ile bazı belgeler verilmiştir. Selahattin bey aile geleneği olarak bugüne kadar zaman zaman vakıf faaliyetleri ile ilgilenmeye devam etmiştir. $\mathrm{Bu}$ belgelerin değerlendirilmesi neticesi aşağıdaki bilgilere ulaşılmıştır. Belgelerin daha iyi anlaşılması bakımından aile şeması şu şekilde oluşturulmuştur.

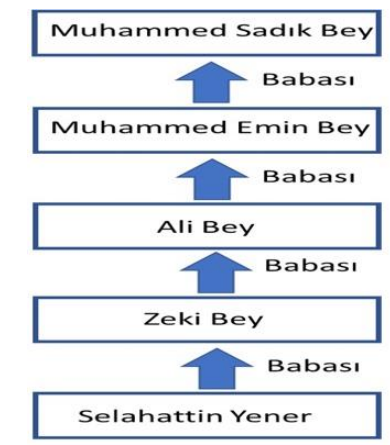

Şekil 1. Aile Şeması

İlk belgede; Muhammed Sadık Bey, Muhammed Emin Bey ve Ali Bey'e ait mühürlere ait bilgiler bulunmaktadır. Bu mühürlerin 19. yüzyılın ikinci yarısına ait olduğu görülmektedir. İlki 1880 tarihlidir. İkincisi, 1881 ve son mühür ise yüzyılın sonuna, yani 1898 tarihli olan bu mühürler üç ayrı kişiye aittir.

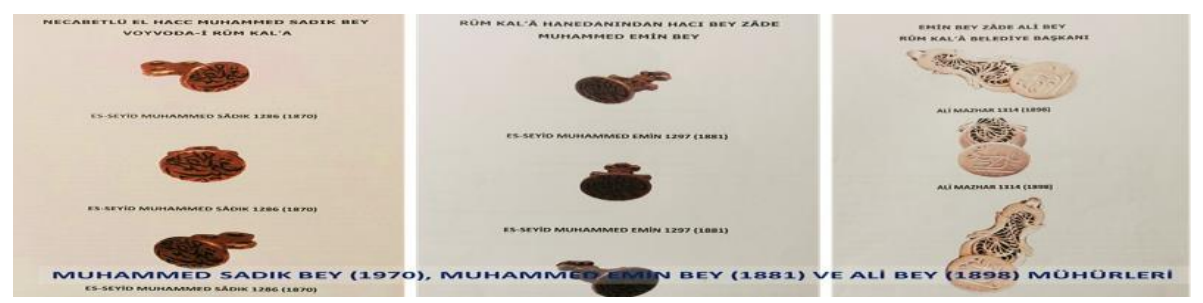

Belge 1. Döneme ait mühürler

Buna göre 1870 tarihli mühürde Muhammed Sadık Bey Volvoda-i Rum Kala unvanı ile anılmaktadır. Aslında "Voyvoda" kelimesi Slav dillerinde 
"kumandan ya da prens" manasında gelir. Eflak ve Boğdan gibi yerler, Osmanlı topraklarına katılmadan önce bu ülke kralları "Voyvoda" olarak isimlendirilirdi. Daha sonra aynı terim Osmanlı İmparatorluğuna bağlı olan bölgelerin yöneticileri için de kullanıldı. Bu anlamdaki Voyvoda ise, Osmanlı imparatorluğunda hazineye ait gelirleri tahsil etmek üzere görevlendirilen kişilerdi (Uzunçarşıl1,1998) ve bunların aynı zamanda görevlendirildikleri yerlerde huzur ve güvenliği sağlamak gibi görevleri de vardi.

Hacı Bey Zade Muhammed Emin Bey'e ait mühürler ise 1881 tarihlidir. Emin Bey'in oğlu Ali Bey'e ait mühürler de 1898 tarihli olup bu tarihte Voyvoda yerine, Rum Kale Belediye Başkanı unvanının kullanıldığı görülmektedir.

1826 yılında Osmanlı Padişahı II. Mahmut tarafından 1826 yılında oluşturulan „Evkaf-1 Hümayun Nezareti“ ile o zamana kadar bir çok birim ve kişilerin idare ettiği vakıflar zamanla bir çatı altında bir araya getirilmiştir.

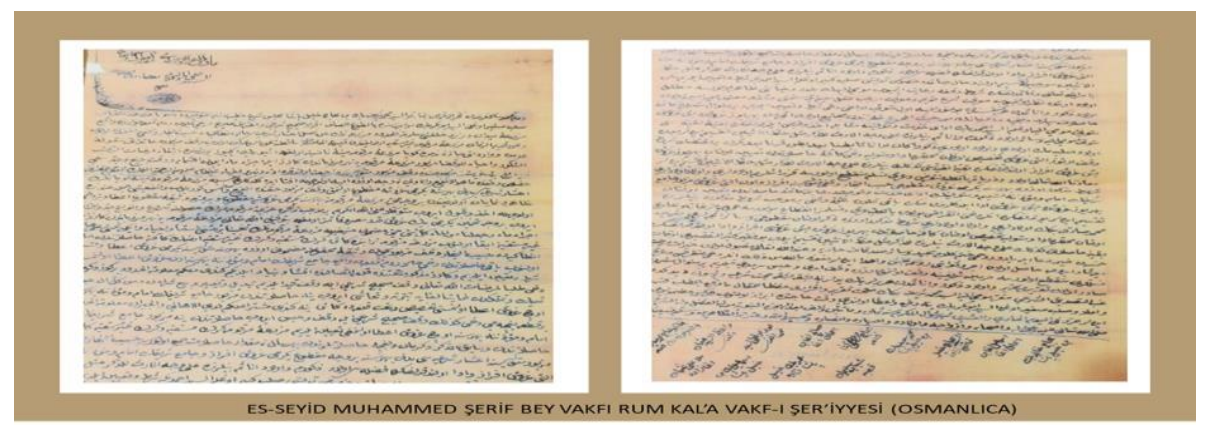

Belge 2. Muhammed Şerif Bey Vakfı Rum Kala Vakf-ı Şer'iyyesi

6 ve 17. yüzyıllarda vakıfların gelirlerini toplamakta Volvodaların önemli görevleri bulunmaktaydı. Bunun için Volvodalar, o bölgede oturanlar arasındaki ehil kişilerden seçilirdi. Aynı şekilde bu yüzyıllarda Rumeli ve Anadolu'da büyük aşiretlerin vergilerini toplamak için görevlendirilenler de "Voyvoda" olarak isimlendirilirdi. Halep de buna dahildi. Aşağıdaki belge de bu dönemlere ilişkin bir vakıf şer'iyye'sidir.

Tazminat sonrasında yapılan düzenlemelerle "Voyvodalık Kurumu" zaman içerisinde kaldırıldı ve kaza müdürleri voyvodaların yaptığı işleri 
üslendi. Bu noktadan hareketle belgelerde Muhammed Sadık Bey "Voyvoda" olarak gösterilirken daha sonraları gösterilmeyişinin altında yatan nedenin muhtemelen bu düzenlemeler olduğu değerlendirilebilir.

$\mathrm{Bu}$ Osmanlıca belgenin günümüz Türkçesine çevrilmiş hali ise aşağıdadır. Burada bahsi geçen hususlardan, o dönemde sistemin işleyişine dair bazı sonuçlara varmak mümkündür.

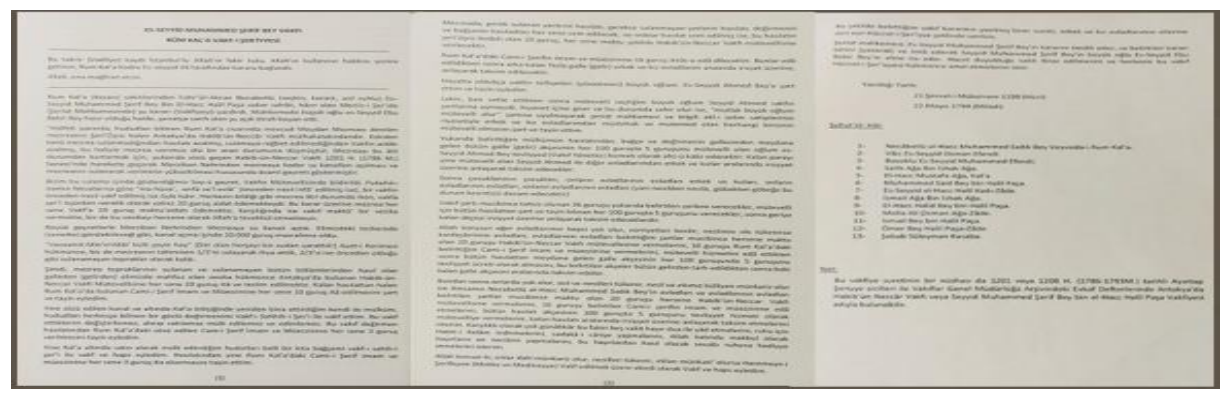

Belge 3. Muhammed Şerif Bey Vakfı Rum Kala Vakf-ı Şer'iyyesi (Türkçe)

Muhammet Şerif Bey Vakfı Rum Kal'a Şer'iyyesi belgesi ve Türkçe çevirisi de muhtemelen yine bu konuda önemli bir gösterge olacaktır. Zaten yapılan düzenlemelerle bu dönemlerde Rumkale'nin de yer değiştirdiği görülmektedir. Rumkale'nin harap olması ve nüfusunun 19. yüzyılda beş haneye kadar inmesi nedeniyle, yerleşim yeri Firat nehrinin karşısına nakledilmiş ve bugünkü Halfeti kurulmuştur. Halfeti 1926 yılına kadar Birecik ilçesine bağlı bir yer iken 1954 yılında Halfeti ilçe haline gelmiştir.

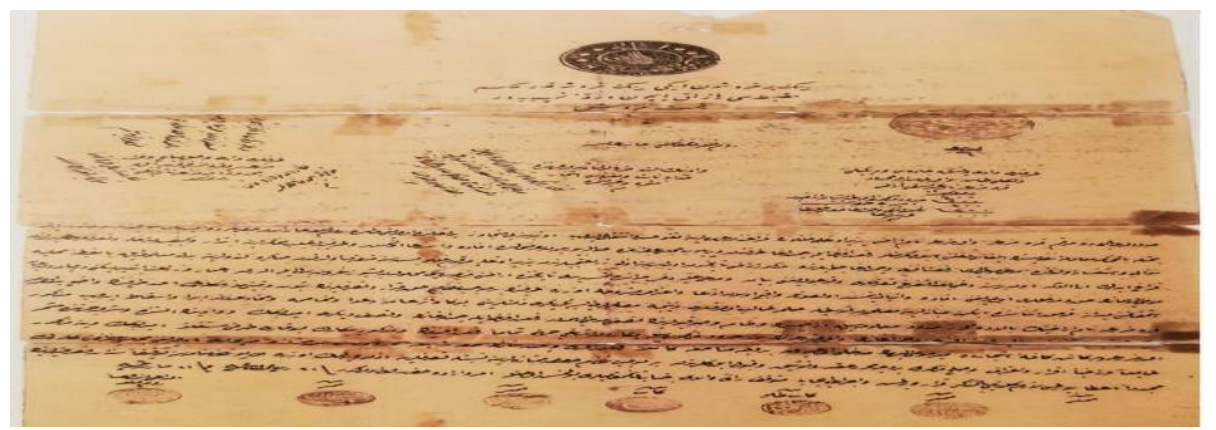

Belge 4. Emin Bey'in Kara ve Ak Mezra'daki itilaflı olan arazilerinin mahkeme sulhnamesi 
Aynı konu ile ilgili olarak itilaflı olan arazilerle ilgili kayıtlar da o döneme ilişkin bilgileri vermektedir. Bu belgede Emin Bey'in Rumkale civarındaki Kara ve Ak Mezralardaki sorunlu arazilere ilişkin "Sulhname" çevirisi yer almaktadır. Belgenin incelenmesinden 1878 tarihli olduğu anlaşılmaktadır.

Belgenin günümüz Türkçesi şu şekildedir.

$\mathrm{Bu}$ belgenin incelenmesinden yazının Rumkale Kaymakamlı̆̆ına hitaben yazıldığı görülmektedir. Belgede Rumkale civarında bulunan 200 hissesi Emin Bey'e, 200 hissesi ise Rıfat Efendi ve Çimen Ağa'ya ait toplam 400 dönüm arazi ile ilgili verilen karardan bahsedilmektedir. Pınardan yukarısı Emin Bey'in hissesi, Pınardan aşağısı Rıfat Efendi hissesi ve geri kalanının ise Rıfat Efendi ve Çimen Ağa' ya ait olduğu bu belgenin başında belirtilmektedir. $\mathrm{Bu}$ belge ile o dönemde belgelerin ne şekilde düzenlendiği ve kararların nasıl verildiğine dair bilgileri elde etmek mümkündür.

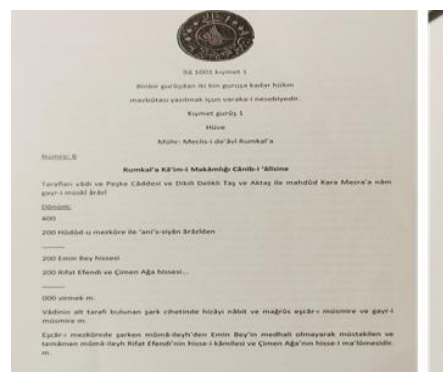

Belge 5. Emin Bey'in Kara ve Ak Mezra'daki itilaflı olan arazilerinin mahkeme sulhnamesi (Türkçe)

Yine başka bir belgede de Ak Mezra'dan yukarısının Emin Bey'e ait olduğunun tescil edildiği görülmektedir. 


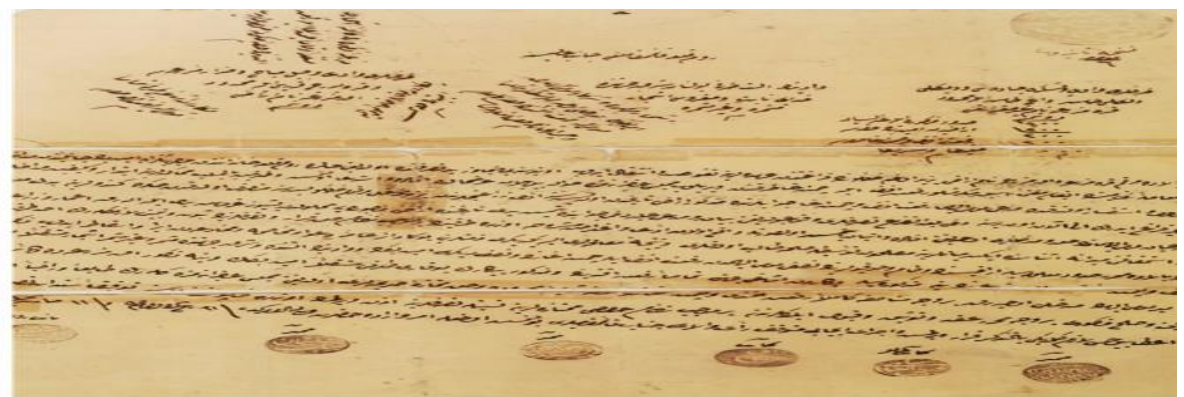

Belge 6. Ak Mezra'da Pınar'dan yukarısının Emin Bey'e ait olduğunun tescili (Osmanlica)

Belgenin günümüz Türkçesi şu şekilde olup yine bu belgenin incelenmesinden dönemine ait bilgiler elde edilebilmektedir.
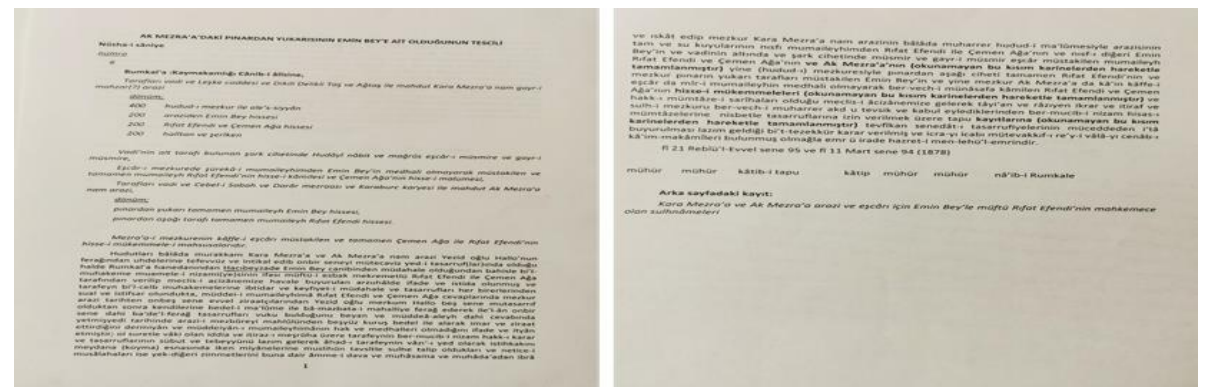

Belge 7. Ak Mezra'da Pınar'dan yukarısının Emin Bey'e ait olduğunun tescili (Türkçe)

Diğer bir belge ise bu döneme ilişkin Emin Bey'e ait bir yüzük olup, bu yüzüğün şimdiki sahibi olan Selahattin Yener'den alınan izin ile resmi çekilerek belgelere eklenmiştir. Yüzük 1870'li yıllara aittir.

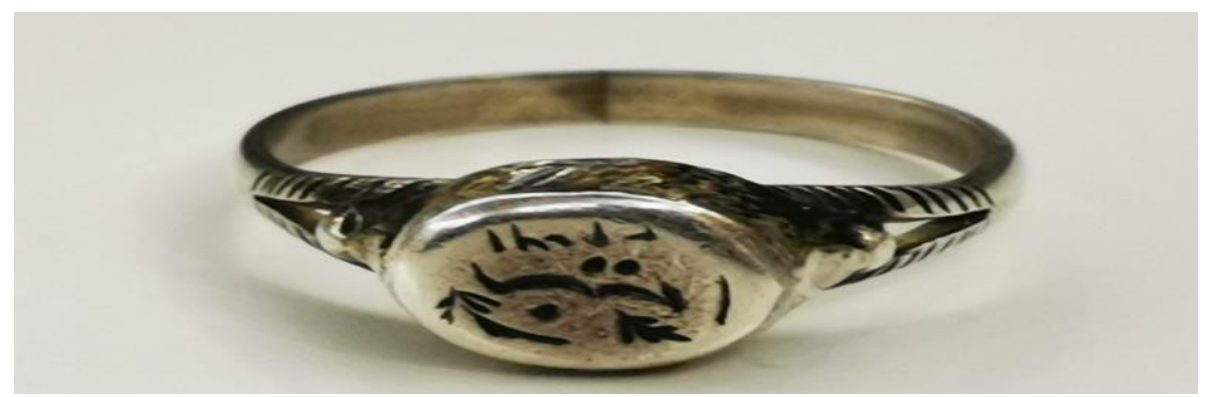

Resim 6. Emin Bey'e ait Yüzük 
1903 tarihli belge de "Devlet-i Aliyye Osmaniyye Tezkeresi" başlıklı olup Emin Bey'in oğlu Ali Bey'in Osmanlı vatandaşı olduğuna dair bir belgedir.
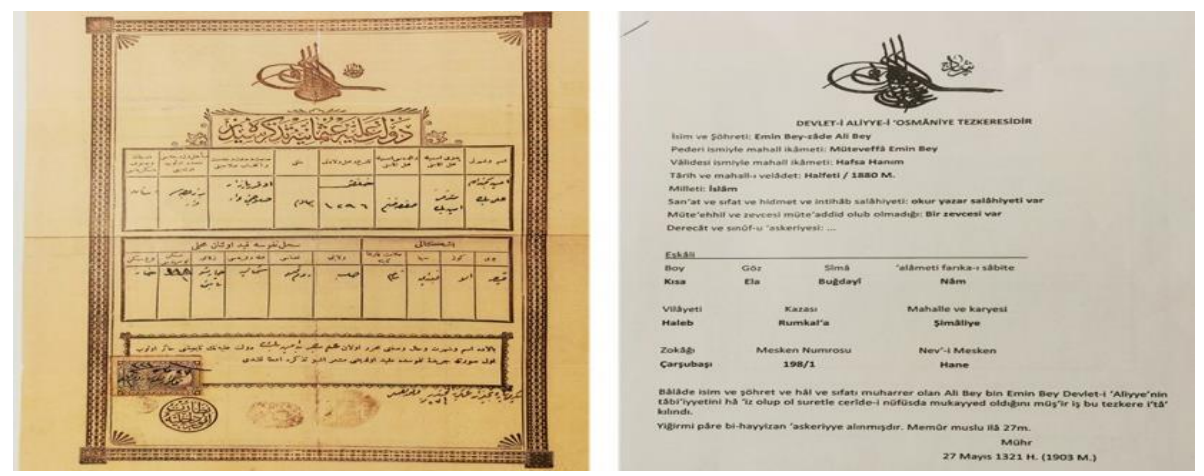

Belge 8. Emin Bey'in Osmanlı Vatandaşı olduğuna dair belge

$\mathrm{Bu}$ belgede o dönemde vatandaş olduğuna dair belgelerin nasıl düzenlendiği de açıkça görülmektedir. Bu belge de Emin Bey'in 1880 doğumlu olduğu ve ona ait diğer bilgiler belirtilmektedir. Bunun ardından gelen belge ise Ali Bey'in Rum Kal'a Belediye Başkanlığ Mazbatasıdır. Bu belge kaza kaymakamı Mustafa Asım tarafından düzenlenmiştir.
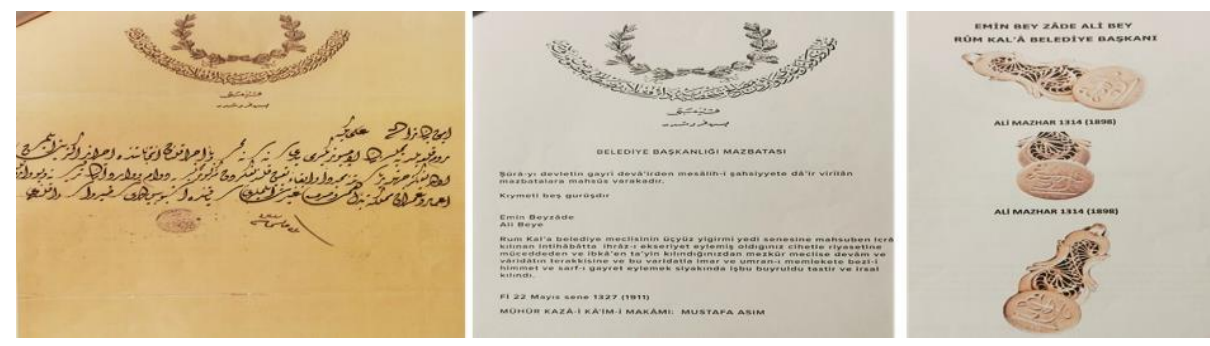

Belge 9. Rum Kal'a Belediye Başkanlığı Mazbatası

Ali Bey tarafından Narlıdere'nin yarı hissesinin kardeşleri Ayşe ve Feride Hanımlara devredilmesine ilişkin resmî belge ise o dönemde devir işlemlerinin yapılış usul ve esaslarına ait bilgiler vermesi açısından özgün bir belge özelliği taşımaktadır. 

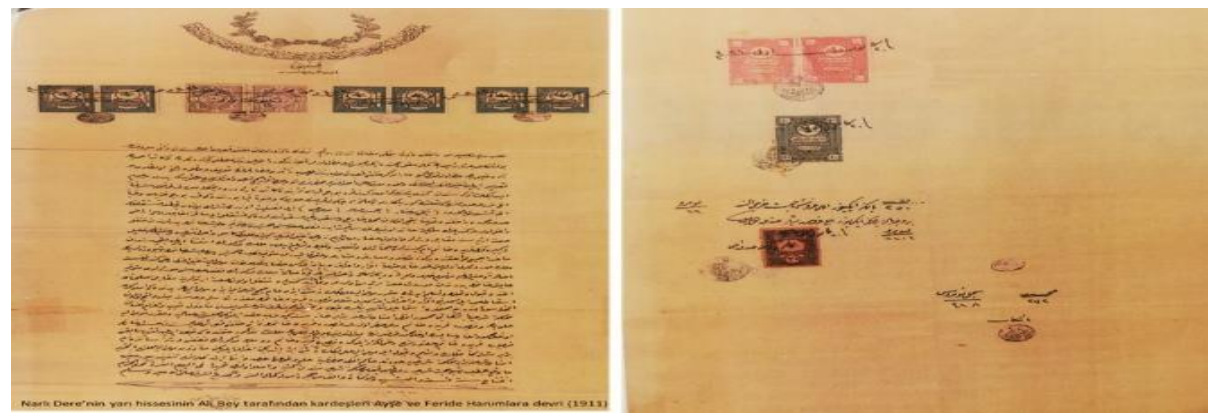

Belge 10. Arazi hisselerinin devredilmesine ilişkin belge (Osmanlıca)
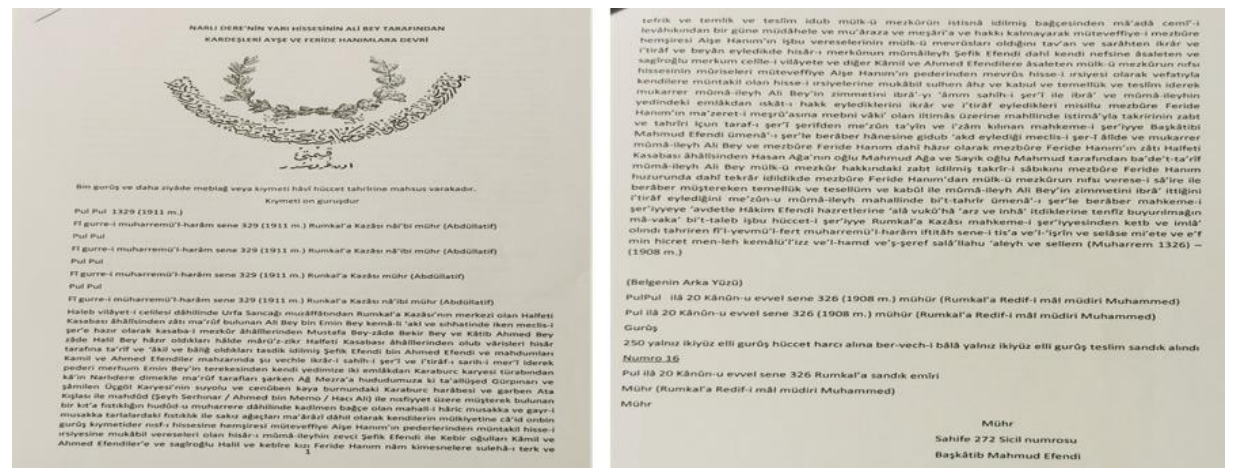

Belge 11. Arazi hisselerinin devredilmesine ilişkin belge (Türkçe)

Aynı şekilde Emin Bey'in kızı Lütfiye hanımın nikah kaydını gösteren belge ise döneminde nikah işlemlerinin yapılışına dair esasları ortaya koymaktadir.
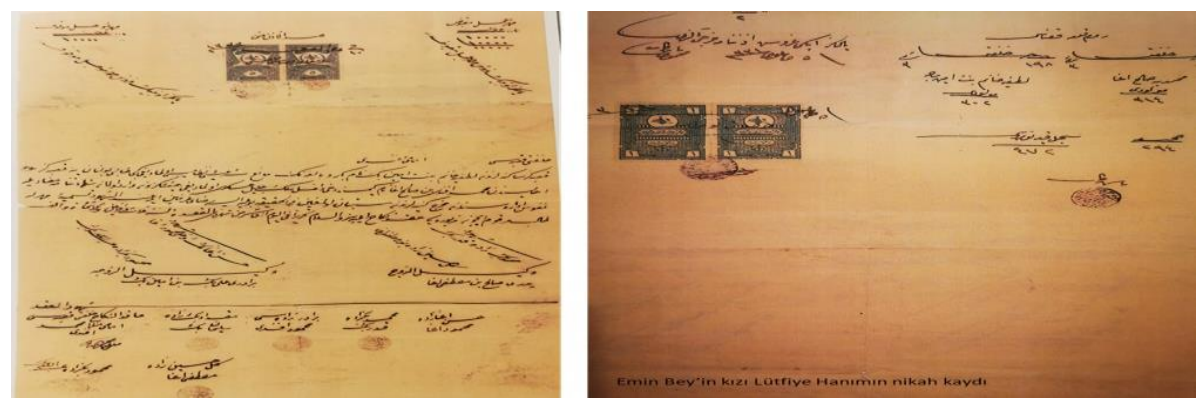

Belge 12. Döneme İlişkin Nikah Kaydını Gösteren Belge 

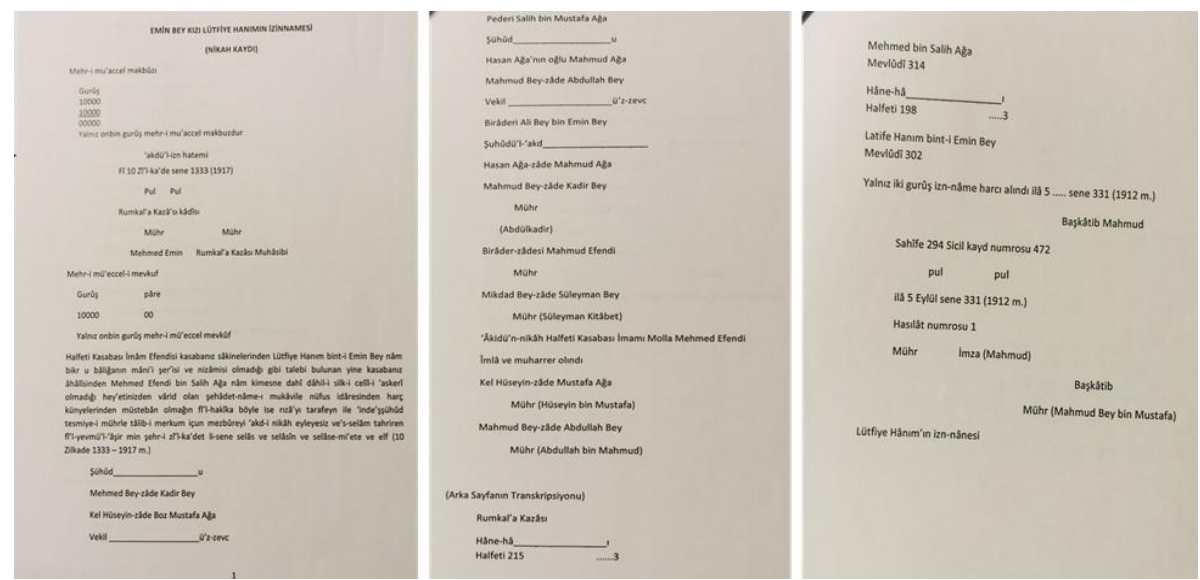

Belge 13. Emin Bey Kızı Lütfiye Hanım İzinnamesi (Türkçe)

Konuyla ilgili son belge ise 29 Mayıs 1928 tarihli Türkiye Cumhuriyeti Maarif Vekaleti İlk Mektep Tasdiknamesidir. Türkiye Cumhuriyeti'nde Arap Alfabesi yerine yeni alfabenin kullanılmaya başlanması 1 Kasım 1928 tarihinde 1358 sayılı kanunla kabul edilmişti. Kanunun yürürlüğe girmesi ise 3 Kasım 1928 tarihinde gerçekleşti. Bu resmî belge ise kanunun yürürlüğe girmesinden yaklaşı 5 ay öncesine ait olup Arap Harfleri ile düzenlenmiştir. Belge Ali Bey oğlu Zeki Efendiye aittir. Belgede Zeki Efendinin 1918 doğumlu olduğu görülmektedir.
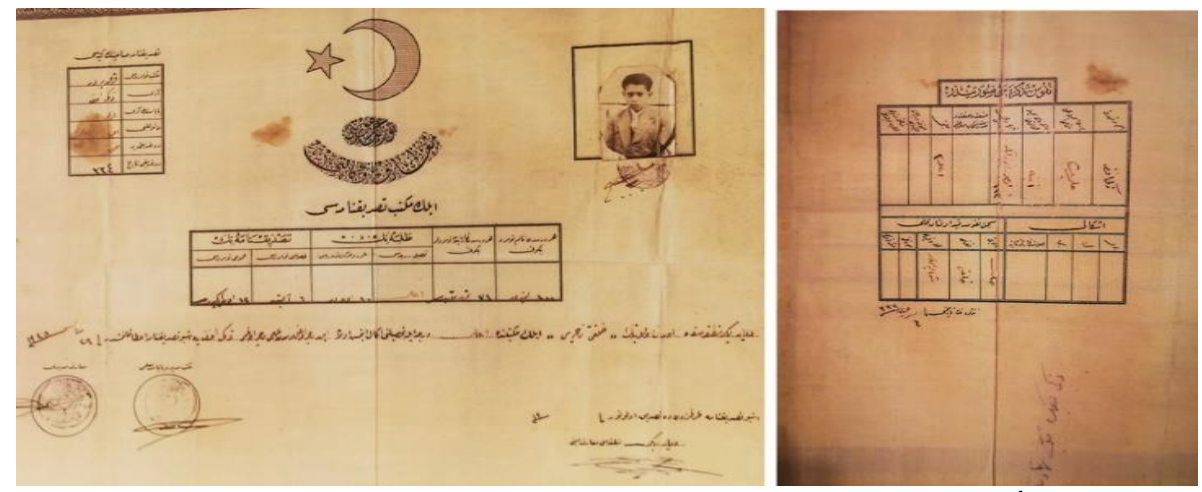

Belge 14: 29 Mayıs 1928 tarihli Türkiye Cumhuriyeti Maarif Vekaleti Ilk Mektep Tasdiknamesi 


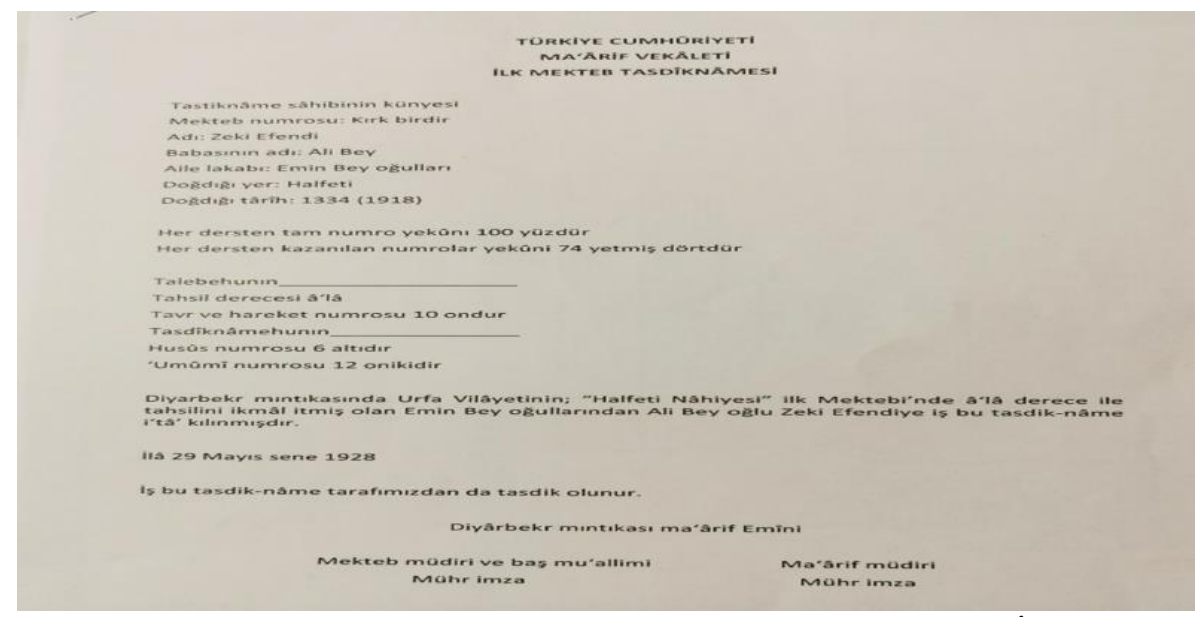

Belge 15. 29 Mayıs 1928 tarihli Türkiye Cumhuriyeti Maarif Vekaleti İlk Mektep Tasdiknamesi (Türkçe)

\section{Sonuç}

Bir yerleşim yeri tarihi ve antropolojik özellikleri ile yaşar. Onu yaşatan aynı zamanda ondan kalan sosyolojik ve kültürel hatıralar, anıtlar, eserler ve yazılı belgelerdir. Bunlar kaybolduğunda ise efsaneleşir ve var ile yok arasında kaybolur gider. Günümüzde Antep ili sınırları içerisinde yer alan Rumkale yerleşkesi bu tanıma en iyi uyan yerlerden birisidir. Derin bir tarih içerisinde birçok medeniyeti yaşatmış olan ve birçok kez el değiştirmiş olan bu mekân, her ne kadar son dönemde kendisi ile ilgili bazı bilgiler basında ve medya da yer alsa da daha fazla araştırılmayı hak ediyor. Ancak bu konuda birbirini tekrar eden kalıplaşmış cümleler Rumkale'yi ve ona ait kültürel değerleri tam olarak izah etmeye yetmiyor. Ona ait değerler giderek azalıyor ve elde kalanlar ise korunmayı hak ediyor. İçinde yaşanılan toplumu anlamaya çalışırken diğer belgeler yanında tarihçi ve antropologlar ise genelde sıradan insanların günlük yaşamlarına ait bilgilere ilgi duyarlar. Bunun asıl nedeni ise birçok resmî belgenin ve tarihsel yazınların kişisel ve taraflı bilgileri yansıtabileceği düşüncesidir. Bu çalışmada Rumkale'ye ait bulunabilen bazı belgelerden hareket ederek ve bölgede yapılan birebir incelemelere dayanılarak bu bölgenin tarihi ve kültürel özellikleri bir derece ortaya konulmaya çalışılmıştır. Kısıtlı bilgilere dayanarak yapılan bu çalışmanın, 
araştırmacılar tarafından daha da geliştirilmesi durumunda, Rumkale ve çevresine ait binlerce yıllık birikimin gelecek kuşaklara aktarılması daha iyi mümkün olabilecektir.

Araştırmalar esnasında tesadüfen bulunan ve günümüzde Gaziantep'in Nizip İlçesi sınırları içerisinde yer alan Rumkale bölgesine ait, Osmanlı Devleti'nin son dönemlerine ilişkin Osmanlıca aile belgeleri de bu türden orijinal belgeler olup dönemine ilişkin bilgileri ihtiva etmektedir. Nadir bulunan bu belgelerin kaybolmaması ve Türkçeye çevrilerek yapılan bir araştırmada kullanılması ise orijinal olması yayında bu bölge ve geçmişine dair bazı bilgileri ortaya koyacak ve daha sonraki araştırmaları kolaylaştıracaktır. Belgeler kayıtlarda adı geçen Rumkale eşrafının soyundan gelen Selahattin Yener'den alınmış olup kendisinden belgelerin yayını için gerekli izin alınmıştır. Bu çalışmanın bir başlangıç olarak bölgenin bir derece anlaşılmasına katkı sağladığı ve bundan sonraki çalışmalar için temel bilgileri bir araya getirdiği düşünülmektedir. 


\section{EXTENDED ABSTRACT}

\section{Rumkale and Its Environment from an Anthropological Perspective \\ *}

Güray Alpar

Stratejik Düşünce Enstitüsü

Rumkale is a region that should be studied with its historical, religious, and geographical location. Rumkale is still located within the borders of Nizip district of Gaziantep. The castle is $62 \mathrm{~km}$ northeast of Gaziantep province.

When the maps printed in the Ottoman period are examined, it is seen that the Rumkale region was shown in the same region with the center of Aleppo at that time. Today, the castle is located on a hill covered with high rocks at the junction of the Euphrates River and Merzimen Stream coming from Yavuzeli, next to the Nizip-Birecik Dam Lake.

A settlement lives with its historical and anthropological features. It is also the sociological and cultural memories, monuments, artifacts, and written documents that keep him alive. When these disappear, they become legendary and disappear between existence and non-existence. Today, Rumkale campus, located within the borders of Antep province, is one of the places that best fits this definition. This place, which has survived many civilizations in a deep history and changed hands many times, deserves to be investigated further, although some information about it has recently appeared in the press and media. However, repetitive stereotypes on this subject are not enough to fully explain Rumkale and its cultural values. Its values are dwindling, and what remains deserves protection. While trying to understand the society they live in, historians and anthropologists are generally interested in information about the daily lives of ordinary people, among other documents. The main reason for this is the thought that many official documents and historical literature may reflect personal and biased information. In this study, it has been tried to reveal the historical and cultural characteristics of this region to some extent, based on some documents that can be found belonging to Rumkale and based on one-to-one investigations in the region. If this 
study, which is based on limited information, is further developed by researchers, it will be possible to transfer thousands of years of experience belonging to Rumkale and its environs to future generations.

Ottoman family documents related to the last periods of the Ottoman Empire, belonging to the Rumkale region, which is located within the borders of Nizip District of Gaziantep and found by chance during the research, are also original documents of this type and contain information about the period. The fact that these rare documents are not lost and used in a research that is translated into Turkish will reveal some information about this region and its past in the publication and will facilitate further research. The documents were taken from Selahattin Yener, who was the descendant of the Rumkale notables mentioned in the records, and the necessary permission was obtained from him for the publication of the documents. It is thought that this study contributes to some understanding of the region as a start and brings together the basic information for future studies.

Selahattin Yener, who is a descendant of Rumkale notables, is a person who spent his childhood in this region and knows the region well. He is still dealing with foundation activities from his family. While some documents in him would probably disappear because no one else was interested, it was recorded with this research. The in-depth information about the cultural characteristics of the region given by the person who is from the people of this region and knows the region well is undoubtedly valuable. The fact that this region is known to a degree with the research carried out in the region also contributed to the understanding of Rumkale, about which there is not much information. In this sense, frequent research in the region during the 1 year in the region contributed to the better understanding and expression of the subject. These studies were also supported by theoretical research and literature review.

By opening the forms of knowledge and analysis, cultural studies push the theories that have been trying to re-understand their own identity to think again and strongly beyond some limitations. Historians and anthropologists are generally more interested in documents that describe the daily lives of ordinary people and provide information about their social lives. The main reason for this is the thought that many official documents and historical writings may reflect the personal and biased 
opinions of the person who wrote that article. Documents belonging to ordinary people, on the other hand, can provide information about the functioning of that society. One task of anthropology in its conceptualized form is to contribute to improving understanding among individuals. Only in this way is it possible for the research area, which serves as a transition between cultures and religions with its deep historical past, to fulfill such a peaceful function. Considering that the aim of sociologists is to try to understand and explain the society in which they live, the Rumkale region deserves such a study. Unless the subject is approached in this way, as some often reveal, the event will continue to be narrated by reducing it to a simple meaning as the thousands-year-old East-West fight.

\section{Kaynakça / References}

Alpar, G. (2014). Antropolojik bakış açısı ile stratejik dünya tarihi. Konya: Palet Yayınları.

Camous, T. (2019). Doğulular Batılılar, yirmi beş asırlık savaş. (Çev. Hande Güreli). İstanbul: Bilge Kültür Sanat.

Erdem, T. (2010). Sosyoloji notları. Ankara: İmaj Yayınevi.

Hal, G. and Birchall C. (2013). Yeni kültürel çalışmalar: Kurumsal serüvenler. (Çev. Onur Kartal). İstanbul: Say Yayınları.

Haviland, A. W. (2002). Kültürel antropoloji. (Çev. Hüsamettin İnaç, Seda Çiftçi). İstanbul: Kaknüs Yayınları.

İbrahim, E. (2006). Türkiye ile Yunanistan arasında Mübadele Meselesi (19231930). Ankara Üniversitesi, Sosyal Bilimler Enstitüsü, Ankara.

Mitchell, S. (2016). Geç Roma İmparatorluğu tarihi. (Çev. Turhan Kaçar). Ankara: Türk Tarih Kurumu yay.

Moltke, von H. (2017). Türkiye mektupları. (Çev. Hayrullah Örs) İstanbul: Remzi Kitapevi.

Murphy, R.E. (2003). Canon, Biblical, New Catholic Encyclopedia, Nşr. Berart L. Washington: Marthaler, I-XV, Thomson and Gale, III.

Plevneli, C. (2017). Avrasya İncelemeleri Dergisi, İstanbul: İstanbul Üniversitesi Press, 2017; VI/1.

Roberts, J. M. (1996). Avrupa tarihi. (Çev. Fethi Aytuna). İstanbul: İnkılap Yayınları. 
Taşdemir, C. (2017). https://medium.com/sec402/sular-alt\%C4\%B1ndaya\%C5\%9Fayan-tarih-rumkale-f4ee2e0a7296 (Alıntı Tarihi: 02 Ocak 2021).

Tahincioğlu, Y. (2011). Tarihleri, kültürleri ve inançlarıyla Süryaniler. İstanbul: Butik.

Uzunçarşılı, H. İ. (1998). Osmanlı Devleti'nin merkez ve bahriye teşkilatı. (3. Baskı. İstanbul: Türk Tarih Kurumu Yayınları.

Ürek, M. (2013). Süryaniler'in tarihi ve sosyolojik yapısı. Milel ve Nihal, 10(2), 95112.

Wulf, C. (2009). Tarihsel kültürel antropoloji. (Çev. Özgür Dünya Sarısoy). Ankara: Dipnot Yayınları.

\section{Kaynakça Bilgisi / Citation Information}

Alpar, G. (2021). Antropolojik yönüyle yaşayan Rumkale ve çevresi. OPUS-Uluslararası Toplum Araştırmaları Dergisi, 18(41), 3679-3704. DOI: 10.26466/opus.879631. 